\title{
Production of Pectinases by $A$. niger: Influence of Fermentation Conditions
}

\author{
María A. Martos ${ }^{1}$, Francisco Martinez Vazquez ${ }^{1}$, Fernando O. Benassi ${ }^{1 *}$ and Roque A. \\ Hours $^{2}$ \\ ${ }^{1}$ Centro de Investigación y Desarrollo Tecnológico; Facultad de Ciencias Exactas, Químicas y Naturales; \\ Universidad Nacional Autónoma de México; Félix de Azara 1552, (3000); Posadas - Misiones - Argentina. ${ }^{2}$ Centro \\ de Investigación y Desarrollo de Fermentaciones Industriales; Facultad de Ciencias Exactas; Universidad \\ Nacional de La Plata; Calle 47 y 115, (1900) La Plata-Argentina
}

\begin{abstract}
Response surface methodology was used for optimization of polygalacturonase (PG) and pectinesterase (PE) production in submerged fermentation by A.niger. A Central Composite Experimental Design was applied, consisting of 22 experiments, including eight central points. Variables studied were: fermentation time (24 to 120 h), $\mathrm{pH}$ (3.5 to 6.5) and initial concentration of pectin (5 to $20 \mathrm{~g} / \mathrm{l}$ ). Maximum PE production was $220 \mathrm{U} / \mathrm{l}$, after $74 \mathrm{~h}$ of culture, in a medium containing $20 \mathrm{~g} / \mathrm{l}$ of pectin ( $\mathrm{pH}$ 6.5). The optimal conditions for $P G$ production were $\mathrm{pH}$ : 4.1, $20 \mathrm{~g} / \mathrm{l}$ of pectin and $94 \mathrm{~h}$ of fermentation with a maximum value of $1032 \mathrm{U} / \mathrm{l}$. Under these conditions, the PE production was low (15 U/l). A liquid extract with high PG activity and low PE activity could be suitable to be used in food processing in order to reduce the production of methanol.
\end{abstract}

Key words: Pectinases; Polygalacturonase; Pectinesterase; Aspergillus niger; Response surface methodology; Citrus pectin

\section{INTRODUCTION}

Pectinases are widely used in industrial processing of fruits and vegetables, because they reduce the viscosity of juices and facilitate extraction, maceration, liquefaction and clarification processes (Naidu and Panda, 1999).

Polygalacturonase (PG) is a depolymerizing enzyme that cleaves glycosidic bonds of pectins by means of hydrolysis. Pectinesterase (PE) is the pectolytic enzyme that catalyzes the hydrolysis of ester links of the pectin molecule. Action of both enzymes is needed in order to obtain complete hydrolysis of the pectin molecule (Taragano and Pilosof, 1999).
Aspergillus niger strains are widely used in several fermentation processes for the production of pectic enzymes. The synthesis of pectinases is induced by pectin or for some of its derivatives (Solís Pereira et al., 1993). The cell growth, sporulation and production of the enzymes can be affected by the composition of the medium and fermentation conditions (Maldonado and Callieri, 1989; Costa et al., 2007).

Most reported studies are carried out varying one factor at a time while keeping the others at a constant level. This approach does not depict the effects of the interactions between the variables. In the present work, response surface methodology was applied to optimize $\mathrm{pH}$, initial pectin concentration and fermentation time conditions on

\footnotetext{
* Author for correspondence: amartos@arnet.com.ar
} 
the production of $\mathrm{PG}$ and $\mathrm{PE}$ by $A$. niger in submerged fermentation.

\section{MATERIALS AND METHODS}

\section{Fermentation medium}

The liquid medium used contained $(\mathrm{g} / \mathrm{l}): \mathrm{KH}_{2} \mathrm{PO}_{4}$, 4; $\mathrm{Na}_{2} \mathrm{HPO}_{4}, 6 ; \mathrm{FeSO}_{4} 7 \mathrm{H}_{2} \mathrm{O}, 0.01 ; \mathrm{CaCl}_{2}, 0.01$; $\mathrm{MgSO}_{4} 7 \mathrm{H}_{2} \mathrm{O}, 0.2 ;\left(\mathrm{NH}_{4}\right)_{2} \mathrm{SO}_{4}, 2 ; \mathrm{H}_{3} \mathrm{BO}_{3}, 10 \mu \mathrm{g} / \mathrm{l}$; $\mathrm{MnSO}_{4}, 10 \mu \mathrm{g} / \mathrm{l} ; \mathrm{ZnSO}_{4} 7 \mathrm{H}_{2} \mathrm{O}, 70 \mu \mathrm{g} / \mathrm{l}$; citrus pectin (Parafarm), 5-20 g/l (Maldonado et al., 1996).

Pectin agar: Idem fermentation medium, citrus pectin $15 \mathrm{~g} / \mathrm{l}$; agar $15 \mathrm{~g} / \mathrm{l}$.

\section{Microorganism}

A. niger $\mathrm{N}^{\circ} 300$, isolated in our laboratory from mouldy citrus fruit peels, was maintained in pectin agar slants. The inoculum was prepared by stirring one-week-old slants with a sterile solution of $0.05 \%$ Tween 80 in water to obtain a $1.2510^{7}$ spores $/ \mathrm{cm}^{3}$ suspension.

\section{Enzyme production}

Two hundred and fifty millilitres Erlenmeyers flasks with $45 \mathrm{ml}$ of medium were inoculated with $5 \mathrm{ml}$ of the inoculum and then incubated at $30{ }^{\circ} \mathrm{C}$ at different times on a rotary shaker at $200 \mathrm{rpm}$.

The biomass was separated by filtration through a paper filter (Whatman $\mathrm{N}^{\circ} 1$ ). The filtrate was stored at $-18^{\circ} \mathrm{C}$ until assayed.

\section{Enzyme assays}

PG activity was determined by incubating $4 \mathrm{ml}$ of $0.5 \%$ polygalacturonic acid (Sigma) in $0.2 \mathrm{M}$ acetate buffer ( $\mathrm{pH} 4.5)$ with $1 \mathrm{ml}$ of the enzyme extract. Reaction was carried out at $37^{\circ} \mathrm{C}$ for 60 min. The release of reducing groups was determined by the dinitrosalicylic acid method (Miller, 1959). A calibration curve was made using galacturonic acid (Sigma) as standard. One unit of PG was defined as the amount of enzyme that released $1 \mu \mathrm{mol}$ of galacturonic acid per minute (Maldonado and Strasser de Saad, 1998).

PE activity was measured by adding $2 \mathrm{ml}$ of the enzyme extract to $10 \mathrm{ml}$ of $0.5 \%$ citrus pectin (Sigma) in $0.1 \mathrm{M} \mathrm{NaCl}$, the $\mathrm{pH}$ was adjusted to 4.5 with $0.1 \mathrm{M} \mathrm{NaOH}$. The reaction was carried out at $35^{\circ} \mathrm{C}$ for $60 \mathrm{~min}$. The amount of equivalents due to the carboxyl groups released was measured by titration with $0.02 \mathrm{~N} \mathrm{NaOH}$. One unit of PE was defined as the amount of enzyme that released 1 $\mu$ mol of carboxyl groups per minute (Maldonado et al., 1996).

\section{Experimental design}

The experimental design selected analyzed three variables at five levels (design type $\mathrm{CCD}=22$ runs, including eight central points for experimental error detection) (Freund and Wilson, 1997). Variables studied were: fermentation time (24 to $120 \mathrm{~h}$ ), initial $\mathrm{pH}$ (3.5 to 6.5$)$ and initial pectin concentration (5 to $20 \mathrm{~g} / \mathrm{l})$.

Real and transformed variables according to the experimental design selected are presented in Table 1.

Regression linear analysis was used to eliminate terms of $\mathrm{P}>0,05$.

All the experiments were conducted in triplicate and the results showed the mean values of the activities.

Table 1 - Experimental variables in real and transformed values

\begin{tabular}{lccc}
\hline & Time (h) & PH & Pectin (g/l) \\
\hline$+\alpha^{*}$ & 120 & 6.5 & 20.0 \\
+1 & 100.54 & 5.892 & 16.956 \\
0 & 72 & 5.0 & 12.5 \\
-1 & 43.46 & 4.108 & 8.040 \\
$-\alpha^{*}$ & 24 & 3.5 & 5.0 \\
\hline
\end{tabular}

$* \alpha=1.68179$.

\section{RESULTS AND DISCUSSION}

Table 2 presents the treatment combinations and responses. The regression coefficients of the equations relating the enzymes production with the variables studied and the respective levels of significance are shown in Table 3.

Figs 1 to 4 show the response surfaces and contour plots for PG and PE production as a function of two independent variables with the other one at a 
given constant level.

All the equations presented a very good adjustment with experimental data $\left(\mathrm{R}^{2}\right.$ coefficients $>0.8$ ) (Table 3).

The three independent variables had significant linear effects on PG production (Table 3). Pectin had a linear and positive effect: a high PG production was observed when pectin concentration was increased (Fig. 1).

The negative values of quadratic effects for $\mathrm{pH}$ and time indicated the existence of a maximum as a function of these variables (Table 3).

Optimum PG production was observed for $\mathrm{pH} 4.1$ and $94 \mathrm{~h}$ of culture (Fig. 2).

Table 2 - Treatment combinations and mean responses.

\begin{tabular}{rccccc}
\hline Run & Pectin $(\mathbf{g} / \mathbf{l})$ & Time $(\mathbf{h})$ & $\mathbf{p H}$ & $\mathbf{P G}(\mathbf{U} / \mathbf{l})$ & PE (U/I) \\
\hline 1 & -1 & -1 & -1 & 654 & 33 \\
2 & 0 & $-\alpha$ & 0 & 726 & 23 \\
3 & -1 & +1 & -1 & 915 & 51 \\
4 & -1 & -1 & +1 & 650 & 57 \\
5 & 0 & 0 & 0 & 799 & 58 \\
6 & 0 & 0 & 0 & 863 & 49 \\
7 & 0 & 0 & 0 & 881 & 51 \\
8 & 0 & $+\alpha$ & 0 & 852 & 33 \\
9 & 0 & 0 & 0 & 958 & 60 \\
10 & +1 & +1 & +1 & 829 & 142 \\
11 & 0 & 0 & $+\alpha$ & 608 & 210 \\
12 & +1 & -1 & +1 & 676 & 72 \\
13 & 0 & 0 & 0 & 872 & 59 \\
14 & $+\alpha$ & 0 & 0 & 988 & 50 \\
15 & 0 & 0 & 0 & 808 & 57 \\
16 & $-\alpha$ & 0 & 0 & 680 & 7 \\
17 & -1 & +1 & +1 & 685 & 33 \\
18 & 0 & 0 & 0 & 898 & 57 \\
19 & +1 & +1 & -1 & 923 & 42 \\
20 & +1 & -1 & -1 & 862 & 37 \\
21 & 0 & 0 & $-\alpha$ & 934 & 69 \\
22 & 0 & 0 & 0 & 898 & 43 \\
\hline
\end{tabular}

PG: polygalacturonase activity. PE: pectinesterase activity.

Table 3 - Regressions coefficients and levels of significance.

\begin{tabular}{lcccc}
\hline & \multicolumn{2}{c}{ PG activity } & PE activity \\
\hline Independent term & Constant & Level of significance & Constant & Level of significance \\
Time & -461.541 & & 857.421 & \\
$\mathrm{pH}$ & $7.65078^{*}$ & 0.0035 & $1.92157^{*}$ & 0.0001 \\
$\mathrm{Pectin}$ & $405.149 *$ & 0.0001 & $-378.546^{*}$ & 0.0153 \\
$\mathrm{pH}^{2}$ & $14.8432^{*}$ & 0.0006 & $-3.68687^{*}$ & 0.0000 \\
$\mathrm{t}^{2}$ & $-49.2359^{*}$ & 0.0158 & $35.8914^{*}$ & 0.0390 \\
$\mathrm{Pectin}^{2}$ & $-0.0402687^{*}$ & 0.0380 & $-0.0133442^{*}$ & 0.0419 \\
$\mathrm{pH}{ }^{*}$ pectin & $* *$ & & $-0.537691^{*}$ & 0.0292 \\
$\mathrm{R}^{2}$ & $* *$ & & $4.0541^{*}$ & \\
\hline
\end{tabular}

* Significant $(\mathrm{P}<0,05), * *$ not significant $(\mathrm{P}>0,05)$ 


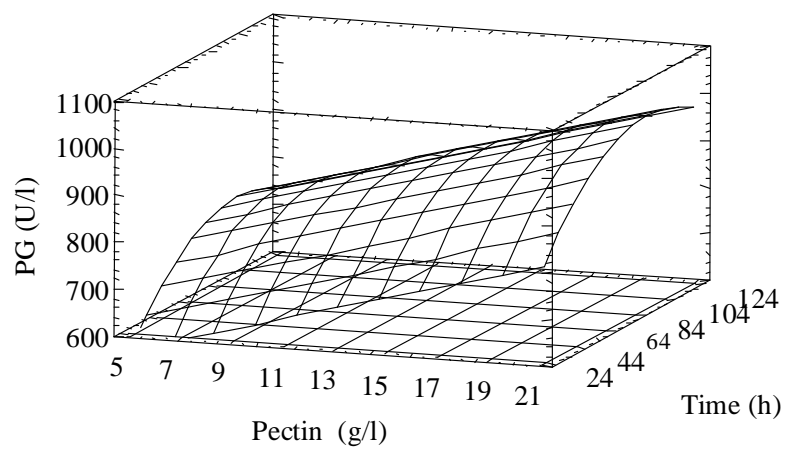

Figure 1 - Effects of fermentation time and initial pectin on PG production (pH: 5.0).

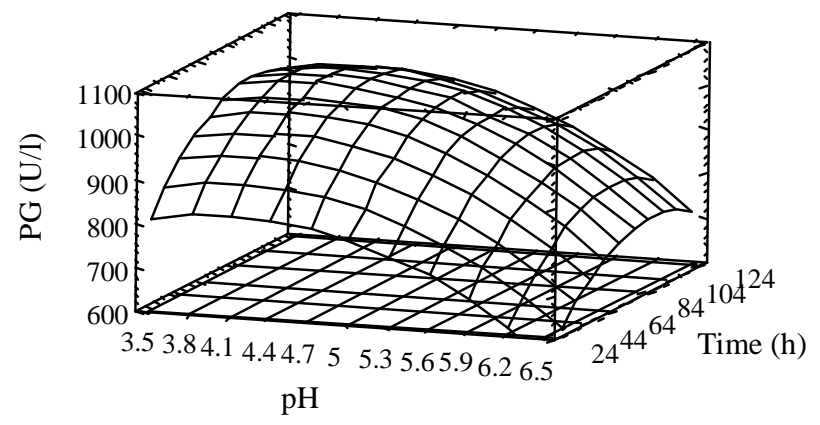

Figure 2 - Effects of fermentation time and initial pH on PG production (initial pectin concentration: $20 \mathrm{~g} / \mathrm{l})$.

No significant interactions were observed among the variables (Table 3 ).

Low PG values obtained at about $\mathrm{pH} 6.5$ were in agreement with those reported by Solís Pereira et al. (1993). Acuña-Argüelles et al. (1995) studied the stability of Aspergillus niger $\mathrm{CH} 4 \mathrm{PG}$ in submerged fermentation as a function of $\mathrm{pH}$ and observed that the enzyme was quickly denatured for $\mathrm{pH}$ values higher than 5.0.

Low initial pectin concentrations yield low pectinases production, since pectinases are generally inducible enzymes (Naidu and Panda, 1998; Malvessi and Silveira, 2004).

The three variables studied had significant linear effects on PE production (Table 3).
The $\mathrm{pH}$ showed positive quadratic effects, indicating a minimum as a function of this variable at the range $4.2-4.8$ (Fig. 3).

Interaction between $\mathrm{pH}$ and pectin was significant and positive (Table 3), and low $\mathrm{pH}$ values did not affect $\mathrm{PE}$ production, but the effect was strongly positive at higher $\mathrm{pH}$ values (Fig. 3). The highest $\mathrm{PE}$ production was obtained at $\mathrm{pH} 6.5$ and $20 \mathrm{~g} / \mathrm{l}$ of pectin.

Table 4 showed that PE production slightly increased at about $74 \mathrm{~h}$ of fermentation.

At $\mathrm{pH}$ higher than 5.0, PE production increased with pectin since the synthesis of this enzyme was induced by this substrate(Maldonado and Callieri, 1989; Maldonado et al., 1994). 


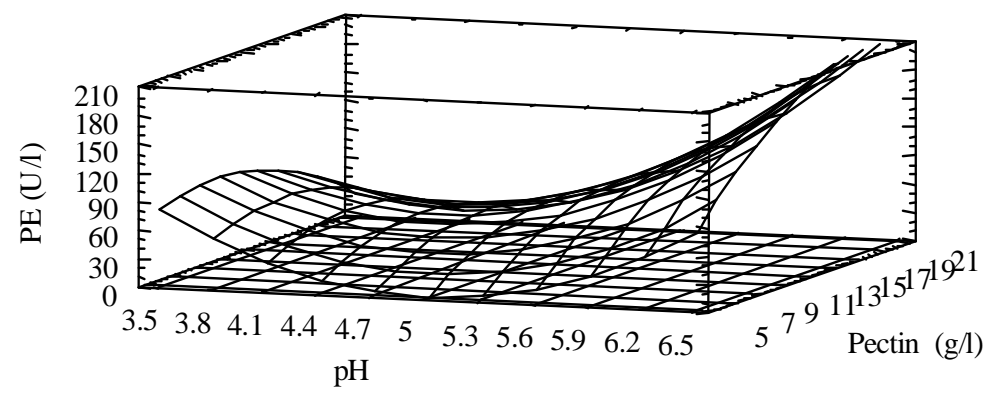

Figure 3 - Effects of initial pectin concentration and pH on PE production (fermentation time: $72 \mathrm{~h}$ ).

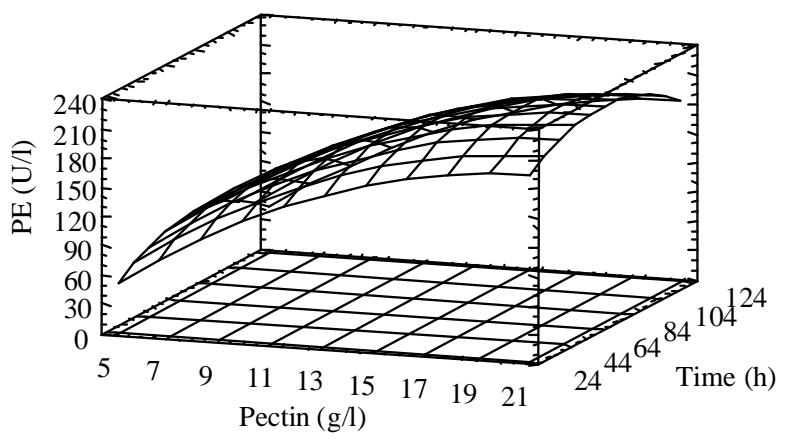

Figure 4 - Effects of fermentation time and initial pectin concentration on PE production (pH: 6.5).

\section{CONCLUSIONS}

Maximum PE production was $220 \mathrm{U} / \mathrm{l}$ at $74 \mathrm{~h}$ of culture, $20 \mathrm{~g} / \mathrm{l}$ of pectin and $\mathrm{pH} 6.5$.

Optimum conditions for PG production were $94 \mathrm{~h}$ of incubation, $20 \mathrm{~g} / \mathrm{l}$ of pectin and $\mathrm{pH} 4.1$. Under these conditions PG production was $1032 \mathrm{U} / 1$ and $\mathrm{PE}$ production was only $15 \mathrm{U} / \mathrm{l}$.

A liquid extract with a high PG activity would accelerate the depolymerization of the pectin molecule while a low PE activity could be advantageous for processing juices taking into account PE liberated methanol that would damage the volatile ester content responsible for the specific scent of fruits.

\section{RESUMO}

A metodologia de superfície de resposta foi utilizada para a otimização da produção de poligalacturonasa $(\mathrm{PG})$ e pectinesterasa $(\mathrm{PE})$, por A. niger em fermentação submergida. Foi aplicado um Desenho Experimental Composto Central abrangendo 22 experiências, incluindo oito pontos centrais. As variáveis estudadas foram: tempo de fermentação (24 a 120 h), pH (3.5 a 6.5) e concentração inicial de pectina $(5$ a $20 \mathrm{~g} / \mathrm{l})$. A produção máxima de PE foi de $220 \mathrm{U} / \mathrm{l}$, após $74 \mathrm{~h}$ de cultivo, $20 \mathrm{~g} / \mathrm{l}$ de pectina e $\mathrm{pH}$ 6.5. As condições ótimas para a produção de $\mathrm{PG}$ foram $\mathrm{pH}$ 4.1, $20 \mathrm{~g} / \mathrm{l}$ de pectina e $94 \mathrm{~h}$ de fermentação, com um valor máximo de 1032 U/l. Sob estas condições, a produção de PE foi baixa (15 U/l). Um extrato líquido com alta atividade PG e baixa atividade PE poderia ser conveniente para ser utilizado no processamento e alimentos, visando reduzir a produção de metanol. 


\section{REFERENCES}

Acuña Argüelles, M.E.; Gutiérrez Rojas, M.; ViniegraGonzález, G.; Favela Torres, E. (1995), Production and properties of three pectinolytic activities produced by Aspergillus niger in submerged and solid state fermentation. Appl. Microbiol. Biotechnol., 43, 808-814.

Costa, J. A. V.; Colla, E.; Magagnin, G.; Oliveria dos Santos, L.; Vendruscolo, M.; Bertolin, T.E. (2007), Simultaneous amyloglucosidase and exopolygalacturonase production by Aspergillus niger using solid-state fermentation. Braz. arch. biol. technol. 50, 759-766.

Freund, R.J. and Wilson, W.J. (1997), Statistical Methods. Academic Press, New York.

Maldonado, M.C. and Callieri, D.A.S. (1989), Influence of environmental conditions on the production of pectinesterase and polygalacturonase by Aspergillus niger. MIRCEN J., 5, 327-333.

Maldonado, M.C. and Strasser de Saad, A. M. (1998), Production of pectinesterase and polygalacturonase by Aspergillus niger in submerged and solid state systems. J. Indust. Microbiol. Biotechnol., 20, 34-38.

Maldonado, M.C.; Strasser de Saad, A.M.; Callieri, D. (1994), Purification and characterization of pectinesterase produced by a strain of Aspergillus niger. Curr. Microbiol., 28, 193-196.

Maldonado, M.C.; Strasser de Saad, A.M.; Callieri, D.A.S. (1996), Effects of aeration and agitation on the production of pectinesterase, polygalacturonase and pectinlyase by a strain of Aspergillus niger. Microbiol.-Alim.-Nutrit., 14, 373-379.
Malvessi, E. and Silveira, M.M. (2004), Influence of medium composition and $\mathrm{pH}$ on the production of polygalacturonases by Aspergillus oryzae. Braz. arch. biol. technol. 47, 693-702.

Miller, G.L. (1959), Use of dinitrosalicylic acid reagent for determination of reducing sugar. Anal. Chem., 31, 426-428.

Naidu, G. and Panda, T. (1998), Production of pectolytic enzymes, a review. Bioproc. Eng., 19, 355361.

Naidu, G. and Panda, T. (1999), Performance of pectolytic enzymes during hydrolisis of pectic substances under assay conditions: a statistical approach. Enzyme Microb. Technol.., 25, 116-124.

Solís Pereira, S.; Favela Torres, E.; Viniegra González, G.; Gutiérrez Rojas, M. (1993), Effects of different carbon sources on the synthesis of pectinase by Aspergillus niger in submerged and solid state fermentations. Appl. Microbiol. Biotechnol., 39, 3641.

Taragano, V.M. and Pilosof, A.M.R. (1999), Application of Doehlert designs for water, $\mathrm{pH}$ and fermentation time optimization for $A$. niger pectinolytic activities production in solid-state and submerged fermentation. Enzyme Microb. Technol., 25, 414- 419.
Received: October 20, 2006; Revised: July 18, 2007; Accepted: July 28, 2008. 